\title{
Implementasi Pengembangan Materi Ajar Interferensi Leksikon Bahasa Inggris ke dalam Bahasa Indonesia Berbasis Media Komunikasi Elektronik Youtube
}

\author{
Indah Isti Widyatama ${ }^{1}$, Abdul Ngalim ${ }^{2}$, Markhamah ${ }^{3}$ \\ ${ }^{1,2,3}$ Universitas Muhammadiyah Surakarta, Indonesia
}

DOI: 10.23917/humaniora.v22i2.8977

Submit: 5 Oktober 2019. Revisi: 20 November 2020. Diterima: 19 Juni 2021 Available Online: 7 Juli 2021. Periode Terbit: Agustus 2021

\begin{tabular}{l}
\hline Kata Kunci \\
\hline english, \\
lexicon interference, \\
learning materials, \\
youtube
\end{tabular}

Corresponding Author

Indah Isti Widyatama

Universitas Muhammadiyah

Surakarta

Indonesia

Email:

indah.istiwidyatama@yahoo.com

Telp: -

\section{Abstrak}

This study has two objectives: (1) to identify interference of the English lexicon into Indonesian used on Youtube and (2) to identify the implementation of the development of Youtubebased English lexicon interference teaching material into Indonesian. This research is a qualitative description which involve data in the form of video from Youtube. The collection techniques are using listening methods and collecting recordings, taking notes, observation and focus group discussions which involve studens. The data analysis technique uses translational equivalent method and the aggregate method. The results of this study show that there are six forms of interference of the English lexicon into the Indonesian language. (a) 39 nouns, (b) 6 verbs, (c) 3 pronouns, (d) 1 conjunction, (e) 3 adverbs, and $(f) 8$ adjectives. This finding is useful in the implementation of sociolinguistic learning with lexicon interference material from English into Indonesian based on the standard set by the Ministry of Education.

\begin{tabular}{l}
\hline Kata Kunci \\
\hline bahasa inggris, \\
interferensi leksikal, \\
materi ajar, \\
youtube
\end{tabular}

Abstrak
Penelitian ini memiliki dua tujuan: (1) mengidentifikasi inter-
ferensi leksikon bahasa Inggris ke dalam bahasa Indonesia
berbasis media komunikasi elektronik Youtube dan (2) men-
gidentifikasi implementasi pengembangan materi ajar inter-
ferensi leksikon bahasa Inggris ke dalam bahasa Indonesia
berbasis media komunikasi elektronik Youtube. Jenis
penelitian ini adalah deskripsi kualitatif. Sumber data
penelitian ini berupa video dari media komunikasi elektronik
Youtube. Teknik pengumpulan data adalah dengan metode
simak dan teknik nontes seperti teknik rekam, catat, observasi
serta FGD (Focus Group Discussion). Teknik analisis data
dalam penelitian ini menggunakan metode padan translasional
dan metode agih. Hasil dari penelitian ini menunjukkan bahwa
pada interferensi leksikon bahasa Inggris ke dalam bahasa In-
doensia, terdapat enam jenis kelompok kata: (a) nomina ter-
dapat 39 data; (b) verba ada 6 data; (c) pronomina 3 data; (d)
konjungsi 1 data; (e) adverbia 3 data; dan (f) adjektiva 8 data.
Hasil penelitian ini bermanfaat dalam implementasi pembelaja-
ran sosiolinguistik dengan materi interferensi leksikon dari
bahasa Inggris ke dalam bahasa Indonesia pada KD 6.1 men-
guraikan konsep dan fenomena interferensi leksikon disertai
dengan contoh kasusnya.

Penelitian ini memiliki dua tujuan: (1) mengidentifikasi interferensi leksikon bahasa Inggris ke dalam bahasa Indonesia berbasis media komunikasi elektronik Youtube dan (2) mengidentifikasi implementasi pengembangan materi ajar interberbasis media komunikasi elektronik Youtube. Jenis penelitian ini adalah deskripsi kualitatif. Sumber data penelitian ini berupa video dari media komunikasi elektronik Youtube. Teknik pengumpulan data adalah dengan metode serta FGD (Focus Group Discussion). Teknik analisis data dalam penelitian ini menggunakan metode padan translasional dan metode agih. Hasil dari penelitian ini menunjukkan bahwa doensia, terdapat enam jenis kelompok kata: (a) nomina terdapat 39 data; (b) verba ada 6 data; (c) pronomina 3 data; (d) konjungsi 1 data; (e) adverbia 3 data; dan (f) adjektiva 8 data. Hasil penelitian ini bermanfaat dalam implementasi pembelajaran sosiolinguistik dengan materi interferensi leksikon dari guraikan konsep dan fenomena interferensi leksikon disertai dengan contoh kasusnya. 


\section{PENDAHULUAN}

Bahasa merupakan suatu alat komunikasi yang dapat digunakan dalam situasi dan kondisi, baik untuk berinteraksi maupun bertukar informasi. Nurhayati, (2009) menyatakan bahwa komunikasi merupakan salah satu kebutuhan utama manusia sebagai bagian dari sebuah kelompok sosial. Agar proses komunikasi berjalan lancar, perlu diperhatikan beberapa faktor. Faktor-faktor tersebut antara lain berupa faktor budaya, sosial, penyampaian pesan, pesan yang disampaikan, dan suasana atau situasi.

Kajian sosiolinguistik secara umum mencakup kajian terhadap bahasa dalam konteks sosial dan budaya, ciri, tujuan, serta variasinya yang terjabar dalam bahasa, dialek, idiolek, ragam, register, dan tingkat tutur. Istilah interferensi termasuk peristiwa dasar perihal hasil pengantar unsur asing ke ranah struktur bahasa seperti dalam proses pembelajaran (Ngalim, 2013; Zhang et al., 2013). Pengertian interferensi juga mencakup masuknya elemen bahasa lain ke bahasa tertentu secara paksa karena terjadinya kontak bahasa. Dalam hal ini, kata atau frasa yang mengalami interferensi disebut kata pimjaman (borrowed or loan word, transferred). Penyebutan kata pinjaman tersebut, oleh Kridalaksana (2011) mendefinisikan sebagai kata yang dipinjam dari bahasa lain dan kemudian sedikit banyaknya disesuaikan dengan kaidah bahasa sendiri. Contoh yang disajikan adalah kata pikir dari kata bahasa Arab fikrun 'pikir'.

Ngalim (2013) menyatakan fenomena penggunaan ragam bahasa informal atau terjadinya peristiwa interferensi merupakan hal yang biasa. Justru tidak mungkin kalau dalam situasi informal ada penutur menggunakan ragam bahasa formal. Dalam situasi santai atau informal, sesungguhnya penggunaan ragam bahasa informal bukan sebagai pengacauan atau gangguan, tetapi sebagai suatu kewajaran. Sebaliknya, jika dalam situasi formal penggunaan bahasa yang dipilih ragam bahasa informal, barulah dikatakan terjadi pengacauan atau gangguan. Dalam proses pembelajaran bidang kajian tertentu, seperti bahasa daerah, bahasa asing, komputer, penyebutan telepon genggam (hand phone) dengan berbagai komponennya yang menggunakan istilah bahasa Inggris, disajikan dengan bahasa Indonesia, tidak mungkin tidak terjadi interferensi. Hal inilah, yang unik dalam proses pembelajaran bahasa Indonesia yang berbasis beberapa bidang kajian tersebut. Padahal, dalam forum resmi, seperti halnya dalam forum pembelajaran tersebut, pengguna bahasa dituntut untuk menggunakan bahasa Indonesia yang baku.

Internet dan media dibutuhkan untuk menjaga keberlangsungan komunikasi politik di seluruh dunia, termasuk di Indonesia. Media ini menghubungkan politisi, pendukung partai politik, aktivis, dan partai-partai itu sendiri. Internet juga digunakan untuk mentransmisikan pesan dari pimpinan politik kepada masyarakat dan sebaliknya. Pengguna internet dari tahun ke tahun semakin meningkat dan para ahli komunikasi politik menyadari secara penuh bahwa se- 
makin lama orang menggunakan internet, semakin lama orang akan menghabiskan waktu mereka di depan internet (Arofah, 2015). Oleh karena itu, penggunaan Internet dan media baru oleh para komunikator politik untuk menjangkau sasaran komunikasinya juga semakin meningkat. Penggunaan media baru oleh para komunikator politik marak karena selain tertarik pada penyajiannya dalam mengawinkan teks, audio dan video, media baru juga menawarkan komunikasi dua arah. Keunggulan lain dari media baru sebagai sarana komunikasi politik adalah kemampuannya memotong jalur media tradisional, menghindari proses gatekeeping yang politis dan sensor pemerintah (Arofah, 2015; Johan, 2018).

Youtube adalah media baru berjenis user generated content atau media yang kontennya diciptakan oleh pengguna media itu sendiri. Situs ini menyediakan video digital yang memungkinkan penggunanya untuk melihat, mengunggah dan membagikan video, baik itu video musik, klip dari acara televisi, iklan, serta video yang dibuat sendiri oleh penggunanya dengan bebas. Layanan yang disediakan oleh Youtube gratis dan terbuka untuk publik, baik untuk pengguna yang memiliki akun di Youtube maupun yang tidak memiliki akun karena tidak ingin melakukan registrasi (Arofah, 2015; Johan, 2018)). Pengguna Youtube dapat menyaksikan video, memberi peringkat suka atau tidak suka, meninggalkan komentar, dan melihat berapa kali video ditonton oleh masyarakat umum. Kekuatan dan pengaruh Youtube sebagai media baru telah menginfiltrasi seluruh entitas politik, sosial, dan ekonomi.

Penelitian mengenai pengembangan bahan ajar dan penggunaan interferensi leksikon bahasa Inggris ke bahasa Indonesia, misalnya telah diteliti dalam media komunikasi elektronik internet, sementara pada penggunaan interferensi bahasa juga terdapat di dalam media lainnya, seperti Youtube yang belum pernah diteliti oleh orang lain. Oleh karena itu, penelitian ini dianggap penting dan memiliki urgensi guna mengembangkan bahan ajar.

Is Jakfar (2018) dalam penelitiannya yang berjudul "Interferensi Bahasa Gayo ke dalam Bahasa Indonesia di Kecamatan Jagong Jeget, Kabupaten Aceh Tengah". Persamaan penelitian Is Jakfar (2018) dengan penelitian ini terletak pada interferensi bahasa. Sementara itu, perbedaannya terletak pada objek kajian penelitian, yaitu Is Jakfar (2018) mengkaji interferensi bahasa Gayo ke dalam bahasa Indonesia di kecamatan Jagong Jeget kabupaten Aceh Tengah, sedangkan penelitian ini menggunakan interferensi leksikon bahasa Inggris ke dalam bahasa Indonesia berbasis media elektronik Youtube.

Agustia (2017) dalam penelitiannya yang berjudul "Interferensi Bahasa Indonesia terhadap Pemakaian Bahasa Inggris pada Siswa Kelas VIII SMP” juga sejalan dengan peneilitian ini. Persamaan penelitian Agustia (2017) dengan penelitian ini terletak pada interferensi bahasa. Perbedaannya terletak pada objek kajian penelitian Agustia (2017) yang mengkaji interferensi bahasa Indonesia terhadap pemakaian bahasa Inggris pada siswa kelas VIII SMP. Sementara itu, 
dalam penelitian ini, kami menggunakan interferensi leksikon bahasa Inggris ke dalam bahasa Indonesia berbasis media elektronik Youtube.

Rahimah, Agustina, dan Syahrul (2015) dalam penelitiannya yang berjudul "Interferensi Bahasa Mandailing dalam Bahasa Indonesia Tulis Siswa Kelas VIII Mts. Baharuddin Kecamatan Batang Angkola, Kabupaten Tapanuli Selatan” juga sejalan dengan penelitian ini. Persamaan penelitian Rahimah, Agustina, Syahrul, (2015) dengan penelitian ini terletak pada interferensi bahasa. Perbedaan terletak pada objek kajian penelitian Rahimah, Agustina, dan Syahrul (2015) terletak pada interferensi bahasa Mandailing dalam bahasa Indonesia tulis siswa kelas VIII Mts Baharuddin kecamatan Batang Angkola kabupaten Tapanuli Selatan. Sementara itu, penelitian ini menggunakan interferensi leksikon bahasa Inggris ke dalam bahasa Indonesia berbasis media elektronik Youtube.

Megawati (2016) dalam penelitiannya yang berjudul "Jargon dan Interferensi Bahasa dalam Sinetron Remaja serta Implikasinya terhadap Cerpen Siswa SMA di Jakarta Selatan" juga dijadikan perbandingan dengan penelitian ini. Persamaan penelitian Megawati (2016) dengan penelitian ini terletak pada interferensi bahasa. Perbedaannya terletak pada objek kajian penelitian Megawati (2016) jargon dan interferensi bahasa dalam sinetron Remaja serta implikasinya terhadap cerpen siswa SMA di Jakarta Selatan. Sementara itu, penelitian ini menggunakan interferensi leksikon bahasa Inggris ke dalam bahasa Indonesia berbasis media elektronik Youtube.

Sutarma dan Sadia (2014) dalam penelitiannya yang berjudul "Interferensi Bahasa Indonesia dalam Penggunaan Bahasa Bali pada Lembar Basa Bali "Bali Orti" Harian Bali Post" juga dibandingkan. Persamaan penelitian Sutarma dan Sadia (2014) dengan penelitian ini terletak pada interferensi bahasa. Sementara itu, perbedaan terletak pada objek kajian penelitian Sutarma dan Sadia (2014) interferensi bahasa Indonesia dalam penggunaan bahasa Bali pada lembar basa Bali "Bali Orti" harian Bali Post. Penelitian ini menggunakan interferensi leksikon bahasa Inggris ke dalam bahasa Indonesia berbasis media elektronik Youtube.

Ena (2015) dalam penelitiannya yang berjudul "Penggunaan Youtube sebagai Sumber Belajar Sosiolinguistik Bahasa Inggris" juga sejalan dengan penelitian ini. Perbedaannya terletak pada objek kajian penelitian Ena (2015) penggunaan Youtube sebagai sumber belajar Sosiolinguistik bahasa Inggris sementara penelitian ini menggunakan interferensi leksikon bahasa Inggris ke dalam bahasa Indonesia berbasis media elektronik Youtube.

Arofah (2015) dalam penelitiannya yang berjudul "Youtube sebagai Media Klarifikasi dan Pernyataan Tokoh Politik” juga sejalan dengan penelitian ini. Persamaan penelitian Arofah (2015) dengan penelitian ini terletak pada interferensi bahasa. Sementara itu, perbedaannya terletak pada objek kajian penelitian Arofah (2015) yang penggunaan Youtube sebagai sumber belajar Sosiolinguistik 
bahasa Inggris, sedangkan penelitian ini menggunakan interferensi leksikon bahasa Inggris ke dalam bahasa Indonesia berbasis media elektronik Youtube.

Triyanto dan Endang (2016) berjudul "Interferensi Gramatikal Bahasa Jawa ke dalam Bahasa Indonesia pada Karangan Laporan Peserta Didik SMP”. Persamaan penelitian Triyanto dan Endang (2016) dengan penelitian ini terletak pada interferensi bahasa. Sementyara itu, perbedaannya terletak pada objek kajian penelitian Triyanto dan Endang (2016) yang mengkaji interferensi Gramatikal Bahasa Jawa ke dalam Bahasa Indonesia pada Karangan Laporan Peserta Didik SMP. Sementara itu, penelitian ini menggunakan interferensi leksikon bahasa Inggris ke dalam bahasa Indonesia berbasis media elektronik Youtube.

Fadhal dan Nurhajati (2012) dalam penelitiannya yang berjudul "Identifikasi Identitas Kaum Muda di Tengah Media Digital (Studi Aktivitas Kaum Muda Indonesia di Youtube)" juga sejalan dengan penelitian ini. Persamaan penelitian Fadhal dan Nurhajati, (2012) dengan penelitian ini terletak pada interferensi bahasa. Perbedaannya terletak pada objek kajian penelitian Fadhal dan Nurhajati (2012) identifikasi identitas kaum muda di tengah media digital (studi aktivitas kaum muda Indonesia di Youtube), dan penelitian ini menggunakan interferensi leksikon bahasa Inggris ke dalam bahasa Indonesia berbasis media elektronik Youtube.

Festman, Rodriguez, and Münte (2010) dalam penelitiannya yang berjudul "Perbedaan Individu dalam Pengendalian Gangguan Bahasa pada Bilingual Akhir Terutama Terkait dengan Kemampuan Eksekutif Umum”. Persamaan penelitian Festman, Rodriguez, and Münte (2010) dengan penelitian ini terletak pada interferensi bahasa. Perbedaannya terletak pada objek kajian, yaitu penelitian Festman, Rodriguez, and Münte (2010) mengkaji individu dalam pengendalian gangguan bahasa pada bilingual akhir terutama terkait dengan kemampuan eksekutif umum, dan penelitian ini menggunakan interferensi leksikon bahasa Inggris ke dalam bahasa Indonesia berbasis media elektronik Youtube.

Kaushanskaya dan Marian (2009) dalam penelitiannya yang berjudul "Bilingualism Mengurangi Interferensi Bahasa Asli selama Pembelajaran Novel” juga dibandingkan. Persamaan penelitian Kaushanskaya dan Marian (2009) dengan penelitian ini terletak pada interferensi bahasa. Perbedaan penelitian ini dengan penelitian Kaushanskaya dan Marian (2009) dterletak pada objek kajian penelitian bilingualism mengurangi interferensi bahasa asli elama pembelajaran novel-kata. Sementara itu, penelitian ini menggunakan interferensi leksikon bahasa Inggris ke dalam bahasa Indonesia berbasis media elektronik Youtube.

Shu, Michael, Chi-Ying, dan Andy (2013) dalam penelitiannya yang berjudul "Citra Budaya-budaya Mengganggu Imigran Pemrosesan Bahasa Kedua melalui Pemicuan Gangguan Bahasa Pertama” juga sejalan dengan penelitian ini. Persamaan penelitian Shu, Michael, Chi-Ying and Andy (2013) dengan penelitian ini terletak pada interferensi bahasa. Perbedaan ini dengan penelitian Shu, Michael, Chi-Ying and Andy (2013) terletak pada objek kajian penelitian 
citra budaya-budaya mengganggu imigran pemrosesan bahasa kedua melalui pemicuan gangguan bahasa pertama, dan penelitian ini menggunakan interferensi leksikon bahasa Inggris ke dalam bahasa Indonesia berbasis media elektronik Youtube.

Rehner (2015) berjudul "Learner Beliefs about Sociolinguistic Competence: A. Qualitative Case study of Four University Second Language Learners" juga kami bandingkan. Persamaan penelitian Kaushanskaya dan Rehner (2015) dengan penelitian ini terletak pada interferensi bahasa. Perbedaan penelitian ini dengan penelitian Rehner (2015) terletak pada objek kajian penelitian Learner Beliefs about Sociolinguistic Competence: A. Qualitative Case study of Four University Second Language Learners, dan penelitian ini menggunakan interferensi leksikon bahasa Inggris ke dalam bahasa Indonesia berbasis media elektronik Youtube.

\section{METODE}

Jenis dan strategi penelitian ini menggunakan pendekatan deskriptif kualitatif. Dikatakan termasuk penelitian deskriptif kualitatif karena penelitian ini berupaya untuk mengkaji pola penggunaan interferensi leksikon bahasa Inggris ke dalam bahasa Indonesia berbasis media komunikasi elektronik Youtube. Wujud data penelitian ini adalah kata atau frasa dalam penggunaan interferensi leksikon bahasa Inggris ke dalam bahasa Indonesia berbasis media komunikasi elektronik Youtube.

Metode simak adalah metode pengumpulan data yang dilakukan dengan menyimak penggunaan bahasa pada objek yang diteliti. Teknik pengumpulan data yang digunakan dalam penelitian ini adalah teknik rekam, catat, dan observasi. Selain teknik itu, juga digunakan FGD (Focus Group Discussion) untuk mendiksusikan pola penggunaan interferensi leksikon bahasa Inggris ke dalam bahasa Indonesia berbasis media komunikasi elektronik Youtube.

Analisis data dilakukan dengan metode padan dan metode agih (Sudaryanto, 2015). Jenis metode padan translasional merupakan metode padan yang alat penentunya bahasa lain. Bahasa yang dimaksud adalah bahasa di luar bahasa yang diteliti. Selanjutnya, untuk mengidentifikasi pemakaikan bentuk sapaan yang tepat (pemilihan bentuk sapaan) digunakan metode padan pragmatis dengan alat penentu mitra tutur (Kesuma, 2007)

Keabsahan data yang digunakan oleh peneliti dalam penelitian ini adalah trianggulasi dokumen. Keabsahan data yang digunakan dalam penelitian ini adalah trianggulasi teknik. Trianggulasi adalah teknik pemeriksaan keabsahan data yang memanfaatkan sesuatu yang lain di luar data itu untuk keperluan pengecekan atau sebagai pembanding terhadap data itu (Moleong, 2006). Menurut Sugiyono (2007) trianggulasi diartikan sebagai teknik pengumpulan data yang bersifat menggabungkan dari berbagai teknik pengumpulan data dan sumber data yang telah ada. 


\section{HASIL}

Penelitian ini adalah interferensi leksikon bahasa Inggris ke dalam bahasa Indonesia berbasis media komunikasi elektronik Youtube dan implementasinya interferensi leksikon bahasa Inggris ke dalam bahasa Indonesia sebagai materi ajar pada jenjang perguruan tinggi. Data penelitian ini adalah data kualitatif. Wujud data pada penelitian ini adalah bentuk dan jenis interferensi leksikon bahasa Inggris ke dalam bahasa Indonesia berbasis media elektronik Youtube. Dokumen yang digunakan yaitu jenis informasi dari media komunilasi elektronik Youtube, yang dipublikasikan oleh Deddy Corbuzier, Atta Halilintar, dan Boy William. Metode pengumpulan data adalah dengan metode simak adalah metode pengumpulan data yang dilakukan dengan menyimak penggunaan bahasa pada objek yang diteliti. Di samping metode simak, digunakan juga metode dokumenter. Instrumen yang digunakan dalam penelitian ini berupa lembar observasi dan alat perekam. Selain teknik itu, juga digunakan FGD (Focus Group Discussion) yang melibatkan siswa untuk mendiksusikan pola penggunaan interferensi leksikon bahasa Inggris ke dalam bahasa Indonesia berbasis media komunikasi elektronik Youtube.

Hasil penelitian ini memberikan kontribusi pengetahuan di bidang sosiolinguistik kepada pembaca mengenai interferensi leksikon bahasa Inggris ke dalam bahasa Indonesia berbasis media komunikasi elektronik Youtube. Dengan diketahui karakteristik penggunaan interferensi leksikon bahasa Inggris ke dalam bahasa Indonesia berbasis media komunikasi elektronik Youtube, para linguis, pelajar dan mahasiswa bisa memanfaatkannya sebagai sumber belajar, khususnya belajar mengenai interferensi leksikon (Wijana \& Rohmadi, 2006; Pradjarto, 2015). Selain itu, peneliti ini dapat menjadikan pelengkap dan mengembang implikasi teori-teori interferensi dalam materi ajar sosiolinguistik.

Berkaitan dengan mata kuliah sosiolinguistik objek penelitian ini yaitu interferensi leksikon bahasa Inggris ke dalam bahasa Indonesia yang termasuk ruang lingkup sosiolingusitik. Berdasarkan analisis mengenai interferensi leksikon bahasa Inggris ke dalam bahasa Indonesia terdapat 18 jenis kata yaitu (a) nomina terdapat 5 data, (b) verba 5 data, (c) pronomina 2 data, (d) konjungsi 2 data, (e) adverbia 2 data, dan (f) adjektiva 2 data.

\section{Klasifikasi Interferensi Leksikon Bahasa Inggris ke dalam Bahasa In- donesia}

\section{a. Interferensi Lesikon berupa Nomina}

(1) Om Ded, sekarang adalah father dalam dunia Youtube. (AH, 24)

Data (1) father berasal dari bahasa Inggris dalam Echols dan Shandily, (2014) berarti bapak atau ayah. Penutur menggunakan dua bahasa yaitu bahasa pertama (B1) adalah bahasa Indonesia dan bahasa kedua (B2) baha- 
sa Inggris dalam berkomunikasi. Data (1) termasuk interferensi leksikon berupa nomina.

\section{(2) Kalau semakin kesini itu function. (LM, 36)}

Data (2) function berasal dari bahasa Inggris dalam Echols dan Shandily, (2014) berarti fungsi. Penutur menggunakan dua bahasa yaitu bahasa pertama (B1) adalah bahasa Indonesia dan bahasa kedua (B2) bahasa Inggris dalam berkomunikasi. Data (2) termasuk interferensi leksikon berupa nomina.

\section{(3) Aku gak design, aku bukan designer! (LM, 36)}

Data (3) designer berasal dari bahasa Inggris dalam Echols dan Shandily, (2014) berarti perancang atau pembuat model/pola. Penutur menggunakan dua bahasa yaitu bahasa pertama (B1) adalah bahasa Indonesia dan bahasa kedua (B2) bahasa Inggris dalam berkomunikasi. Data (3) termasuk interferensi leksikon berupa nomina.

\section{(4) Yang selfie banyak orang yang berjilbab. (GM, 38)}

Data (4) selfie berasal dari bahasa Australia dalam Echols dan Shandily, (2014) berarti swafoto. Penutur menggunakan dua bahasa yaitu bahasa pertama (B1) adalah bahasa Indonesia dan bahasa kedua (B2) bahasa Inggris dalam berkomunikasi. Data (4) termasuk interferensi leksikon berupa nomina.

\section{(5) Ini hanya jokes. (GM, 38)}

Data (5) jokes berasal dari bahasa Inggris dalam Echols dan Shandily, (2014) berarti lelucon atau humor. Penutur menggunakan dua bahasa yaitu bahasa pertama (B1) adalah bahasa Indonesia dan bahasa kedua (B2) bahasa Inggris dalam berkomunikasi. Data (5) termasuk interferensi leksikon berupa nomina.

\section{b. Interferensi Lesikon berupa Verba}

(6) Apa yang kita posting itu kita lihat dulu. (DC, 42)

Data (6) posting berasal dari bahasa Inggris dalam Echols dan Shandily, (2014) berarti menempatkan. Penutur menggunakan dua bahasa yaitu bahasa pertama (B1) adalah bahasa Indonesia dan bahasa kedua (B2) bahasa Inggris dalam berkomunikasi. Data (6) termasuk interferensi leksikon berupa verba.

\section{(7) Kakak design baju juga? (AH, 24)}

Data (7) design berasal dari bahasa Inggris dalam Echols dan Shandily, (2014) berarti model atau pola. Penutur menggunakan dua bahasa yaitu 
bahasa pertama (B1) adalah bahasa Indonesia dan bahasa kedua (B2) bahasa Inggris dalam berkomunikasi. Data (7) termasuk interferensi leksikon berupa verba.

(8) Saya juga sering travelling agak gak jenuh. (RM, 40)

Data (8) travelling berasal dari bahasa Inggris dalam Echols dan Shandily, (2014) berarti perjalanan/bepergian. Penutur menggunakan dua bahasa yaitu bahasa pertama (B1) adalah bahasa Indonesia dan bahasa kedua (B2) bahasa Inggris dalam berkomunikasi. Data (8) termasuk interferensi leksikon berupa verba.

(9) Kita tidak update. (DC, 42)

Data (9) update berasal dari bahasa Inggris dalam Echols dan Shandily, (2014) berarti memperbaharui. Penutur menggunakan dua bahasa yaitu bahasa pertama (B1) adalah bahasa Indonesia dan bahasa kedua (B2) bahasa Inggris dalam berkomunikasi. Data (9) termasuk interferensi leksikon berupa verba.

\section{(10) Saya punya perusahaan export. (JW, 58)}

Data (10) export berasal dari bahasa Inggris dalam Echols dan Shandily, (2014) berarti pengeluaran. Penutur menggunakan dua bahasa yaitu bahasa pertama (B1) adalah bahasa Indonesia dan bahasa kedua (B2) bahasa Inggris dalam berkomunikasi. Data (10) termasuk interferensi leksikon berupa verba.

\section{c. Interferensi Lesikon berupa Adjektiva}

(11) Bapak itu orangnya busy banget. (BW, 28)

Data (11) busy berasal dari bahasa Inggris dalam Echols dan Shandily, (2014) berarti sibuk. Penutur menggunakan dua bahasa yaitu bahasa pertama (B1) adalah bahasa Indonesia dan bahasa kedua (B2) bahasa Inggris dalam berkomunikasi. Data (11) termasuk interferensi leksikon berupa adjektiva.

(12) Tapi, ini adalah favorite. (LM, 36)

Data (12) favorite berasal dari bahasa Inggris dalam Echols dan Shandily, (2014) berarti kesukaan. Penutur menggunakan dua bahasa yaitu bahasa pertama (B1) adalah bahasa Indonesia dan bahasa kedua (B2) bahasa Inggris dalam berkomunikasi. Data (12) termasuk interferensi leksikon berupa adjektiva.

\section{d. Interferensi Lesikon berupa Pronomina}

(13) Ini bukan soal agama, semua everything. (AH, 24) 
Data (13) everything berasal dari bahasa Inggris dalam Echols dan Shandily, (2014) berarti semuanya atau segala sesuatu. Penutur menggunakan dua bahasa yaitu bahasa pertama (B1) adalah bahasa Indonesia dan bahasa kedua (B2) bahasa Inggris dalam berkomunikasi. Data (13) termasuk interferensi leksikon berupa pronomina.

(14) We Indonesia teman. (AH, 24)

Data (14) we berasal dari bahasa Inggris dalam Echols dan Shandily, (2014) berarti kami atau kita. Penutur menggunakan dua bahasa yaitu bahasa pertama (B1) adalah bahasa Indonesia dan bahasa kedua (B2) bahasa Inggris dalam berkomunikasi. Data (14) termasuk interferensi leksikon berupa pronomina.

\section{e. Lesikon berupa Konjungsi}

(15) But sekarang, kita bahas sekarang. (DC, 42)

Data (15) but berasal dari bahasa Inggris dalam Echols dan Shandily, (2014) berarti tetapi. Penutur menggunakan dua bahasa yaitu bahasa pertama (B1) adalah bahasa Indonesia dan bahasa kedua (B2) bahasa Inggris dalam berkomunikasi. Data (15) termasuk interferensi leksikon berupa konjungsi.

(16) Kamu and aku saling bertukar pikiran. (DC, 42)

Data (16) and berasal dari bahasa Inggris dalam Echols dan Shandily, (2014) berarti dan. Penutur menggunakan dua bahasa yaitu bahasa pertama (B1) adalah bahasa Indonesia dan bahasa kedua (B2) bahasa Inggris dalam berkomunikasi. Data (16) termasuk interferensi leksikon berupa konjungsi.

\section{f. Interferensi Lesikon Adverbia}

(17) Tuhan gak pernah bikin kita ribut, yang memecahkan kita itu manusia yes hanya untuk membuat orang seperti itu. (AH, 24)

Data (17) yes berasal dari bahasa Inggris dalam Echols dan Shandily, (2014) berarti ya. Penutur menggunakan dua bahasa yaitu bahasa pertama (B1) adalah bahasa Indonesia dan bahasa kedua (B2) bahasa Inggris dalam berkomunikasi. Data (17) termasuk interferensi leksikon berupa adverbia.

(18) Setiap aku ngebaca, so saya sangat takut. (NS, 41)

Data (18) so berasal dari bahasa Inggris dalam Echols dan Shandily, (2014) berarti jadi/juga/begitu/demikian. Penutur menggunakan dua bahasa yaitu bahasa pertama (B1) adalah bahasa Indonesia dan bahasa kedua (B2) bahasa Inggris dalam berkomunikasi. Data (18) termasuk interferensi leksikon berupa adverbia. 


\section{Implementasi Pengembangan Materi Ajar Interferensi Leksikon Baha- sa Inggris ke dalam Bahasa Indonesia Berbasis Media Komunikasi El- ektronik Youtube.}

Berdasarkan hasil penelitian ini, penulis mengimplementasikannya sebagai materi ajar sosiolinguistik pada jenjang perguruan tinggi di Universitas Muhammdiyah Surakarta (UMS). Penyusunan materi ajar tesebut berdasarkan rencama pembelajaran semester (RPS) disesuaikan dengan deskripsi mata kuliah sosiolinguistik serta capaian pembelajaran perkuliahan. Mata kuliah sosiolinguistik wajib diikuti oleh mahasiswa pendidikan bahasa Indonesia pada semester IV.

Materi ajar pada pembelajaran interferensi leksikon bahasa Inggris ke dalam bahsa Indonesia berbasis media komunikasi elektronik Youtube pada Kompetensi Dasar Mata Kuliah nomor 6.1 menguraikan konsep dan fenomena interferensi leksikon disertai dengan contoh kasusnya. Mahasiswa mampu menguasai konsep dan penerapan teoritis serta mampu menerapkan keterampilan tentang interferesnsi leksikon bahasa Inggris ke dalam bahasa Indonesia berbasis media komunikasi elektronik Youtube. Bentuk bentuk pengembangan materi ajar dapat diinovasikan ke dalam bentuk beraneka ragam seperti menggunaan media komunikasi elektronik (Sufanti et al,. 2018; Kartikaputri, 2017) .Rencana pembelajaran semester (RPS) menge-nai interferensi leksikon bahasa Inggris ke dalam bahasa Indonesia berbasis media komunikasi elektronik Youtube.

Pengertian interferensi termasuk peristiwa dasar perihal hasil pengantar unsut asing ke ranah struktur bahasa sehingga seperti dalam proses pembelajaran. Weinreich juga mengemukakan bahwa interferensi masuknya elemen bahasa lain ke bahasa tertentu secara paksa karena terjadinya kontak antar bahasa (Ngalim, 2013). Dalam hal ini, kata atau frasa yang mengalami interferensi disebut kata pimjaman (borrowed or loan word, transferred). Penyebutan kata pinjaman tersebut, oleh Kridalaksana, (2011) didefinisikan kata yang dipinjam dari bahasa lain dan kemudian sedikit banyaknya disesuaikan dengan kaidah bahasa sendiri. Contoh yang disajikan adalah kata pikir dari kata bahasa Arab fikrun 'pikir'.

Jenis-Jenis Interferensi mengidentifikasi interferensi bahasa menjadi tiga macam.

\section{a. Interferensi Fonologis}

Chaer dan Agustina, (2010) menyatakan interferensi fonologis terjadi apabila penutur mengungkapkan kata-kata dari suatu bahasa dengan menyisipkan bunyi-bunyi bahasa dari bahasa lain. Dalam bahasa Indonesia interferensi pada sistem fonologi misalnya, oleh para penutur bahasa Indonesia yang berasal dari Tapanuli. Fonem /ð/ pada kata seperti dan dilafalkan menjadi [dEngan] dan $[\mathrm{rEmbEs}]$.

\section{b. Interferensi Morfologis}


Chaer dan Agustina, (2010) menyatakan interferensi morfologis Interferensi morfologis dipandang oleh para ahli bahasa sebagai interferensi yang paling banyak terjadi.Interferensi ini terjadi dalam pembentuka kata afiks. Afiks- afiks suatu bahasa digunakan untuk membentuk kata dalam bahasa lain. Misalnya, kalau sering kali kita mendengar ada kata kepukul, ketabrak, kebesaran, kekecilan, kemahalan, sungguhan, bubaran, duaan.

\section{c. Interferensi Sintaksis}

Chaer dan Agustina, (2010:122) menyatakan interferensi dalam bidang sintaksis, kita ambil contoh dalam kalimat bahasa Indonesia dari seorang bilingual Jawa-Indonesia dalam berbahasa Indonesia. Bunyi kalimat itu "disini toko laris yang mahal sendiri" kalimat bahasa indonesia ini berstuktur bahasa Jawa, sebab dalam bahasa Jawa bunyinya adalah "ning kene toko laris sing laran dhewe". Kata "sendiri" dalam bahasa indonesia itu merupakan terjemahan dari kata Jawa dhewe. Arti dhewe dalam bahasa Jawa, antara lain memang berarti 'sendiri'. Dengan demikian, kalimat tersebut seharusnya berbunyi "toko laris adalah toko yang paling mahal di sini”.

Berdasarkan analisis mengenai interferensi leksikon bahasa Inggris ke dalam bahasa Indoensia, terdapat 18 jenis kata yaitu (a) nomina terdapat 5 data, (b) verba 5 data, (c) pronomina 2 data, (d) konjungsi 2 data, (e) adverbia 2 data, dan (f) adjektiva 2 data.

\section{PEMBAHASAN}

Dari temuan di atas, dapat ditafsirkan bahwa terdapat sejumlah interferensi leksikon bahasa Inggris ke dalam bahasa Indonesia yang digunakan dalam Youtube. Interferensi leksikal tersebut dapat menunjukkan fenomena sosiolinguistik yang terjadi di tengah masyarakat, yaitu penggunaan campuran bahasa Inggris dengan tujuan prestise. Tujuan prestise mengarah pada rasa bangga dan ingin menunjukkan kemampuan berbahasa asing sehingga memberi kesan prestise yang lebih tinggi.

Dalam implikasinya terhadap pengembangan bahan ajar mata kuliah sosiolinguistik di Universitas Muhammadiyah Surakarta, hasil kajian ini diharaplan dapat menjadi bahasan yang lebih luas mengenai contoh-contoh fenomena sosiolinguistik di masyarakat, khsusunya tentang interferensi bahasa Inggris ke dalam penggunaan bahasa Indonesia sehari-hari.

\section{SIMPULAN}

Berdasarkan analisis data dan pembahasan tersebut ada dua hal yang perlu disimpulkan. Pertama, interferensi leksikon bahasa Inggris ke dalam bahasa Indoensia terdapat 18 jenis kata yaitu (a) nomina terdapat 5 data, (b) verba 5 data, (c) pronomina 2 data, (d) konjungsi 2 data, (e) adverbia 2 data, dan (f) adjektiva 
2 data. Kedua, implementasi pengembangan materi ajar interferensi leksikon bahasa Inggris ke dalam bahasa Indonesia berbasis media komunikasi elektronik Youtube dapat diterapkan. Penerapan ini dapat didasarkan pada capaian pembelajaran pengetahuan dan keterampilan pada KD 6.1 menguraikan konsep dan fenomena interferensi disertai dengan contoh kasus.

\section{DAFTAR PUSTAKA}

Arofah, Kurnia. 2015. "Youtube Sebagai Media Klarifikasi Dan Pernyataan Tokoh Politik". Jurnal Ilmu Komunikasi, 13(2), 111-123.

Ena, FX. Ouda Teda. 2015. "Penggunaan Youtube Sebagai Sumber Belajar Sosiolinguistik Bahasa Inggris". Jurnal Penelitian. 19(1), 23-28.

Festman, J., Rodriguez-Fornells, A., \& Münte, T. F. (2010). Individual differences in control of language interference in late bilinguals are mainly related to general executive abilities. Behavioral and brain functions, 6(1), 112.

Johan, G. M. (2018). Interferensi Morfologis Bahasa Simeulue Dalam Pembelajaran Menulis Karangan Narasi Pada Siswa Kelas V Sd Negeri 10 Simeulue Tengah. Jurnal Metamorfosa, 6(1), 27-39.

Johan, G. M. (2018). Kesalahan Fonologis dalam Proses Diskusi Siswa Sekolah Dasar. Jurnal Metamorfosa, 6(2), 123-133.

Kartikaputri, Rohyati. 2017. "Interferensi Bahasa Melayu Jambi ke dalam Bahasa Indonesia pada Siswa Kelas VIIIa di SMP N 20 Kota Jambi Tahun Ajaran 2016/2017'. Jurnal AKSARA: Jurnal Ilmiah Pendidikan Bahasa dan Sastra Indonesia. 1(1), 63-70.

Kaushanskaya, Margarita and Marian Viorica. 2009. "Bilingualism Reduces Native-Language Interference During Novel-Word Learning". Journal of Experimental Psychology. 35(3), 829-835.

Kesuma, Tri Mastoyo Jati. 2007. Pengantar (Metode) Penelitian Bahasa. Yogyakarta: Caravatibooks.

Kridalaksana, Harimurti. 2011. Kamus Linguistik. Cetakan keempat. Jakarta: PT Ikrar Mandiriabadi.

Moleong, Lexy. J. 2006. Metodologi Penelitian Kualitatif. Bandung: PT Remaja Rosdakarya.

Ngalim, Abdul. 2013. Sosiolinguistik: Suatu Kajian Fungsional dan Analisisnya. Cetakan Pertama. Surakarta: PBSID FKIP UMS.

Pradjarto, J. S. (2015). Interferensi Gramatikal Bahasa Indonesia kedalam Bahasa Inggris dan Implikasinya Terhadap Kemampuan Produktif Pembelajar Bahasa Inggris Tingkat Pemula. Cakrawala: Jurnal Pendidikan, 9(1)

Rehner, Katherine jinsuk Yang. 2015. "Learner Beliefs about Sosiolinguistic Competanse A. Qualitative Case study of Four University Second Language Learners". Cerele S. 5(1), Pages 157-180.

Sudaryanto. 2015. Metode dan Aneka Teknik Analisis Bahasa: Pengantar Penelitian Wahana Analisis secara Linguistik. Yogyakarta: Sanata Dharma University Press.

Sufanti, M., Nuryatin, A., Rohman, F., \& Waluyo, H. J. (2018). Pemilihan Cerita Pendek sebagai Materi Ajar Pembelajaran Sastra oleh Guru Mata Pelajaran 
Bahasa Indonesia SMA di Surakarta. Jurnal Penelitian Humaniora, 19(1), 10-19.

Sugiyono. 2007. Memahami Penelitian Kualitatif. Cetakan Ketiga. Bandung: CV. Alfabeta.

Wijana, I Dewa Putu dan Muhammad Rohmadi. 2006. Sosiolinguistik kajian Teori dan Analisis. Yogyakarta: Pustaka Belajar.

Zhang, S., Morris, M. W., Cheng, C. Y., \& Yap, A. J. (2013). Heritage-culture images disrupt immigrants' second-language processing through triggering first-language interference. Proceedings of the National Academy of Sciences, 110(28), 11272-11277. 